\title{
Evaluation of malting properties and activities of three enzymes from sorghum (Sorghum bicolor) during malting
}

\author{
David Morakinyo Sanni and Toluwase Hezekiah Fatoki
}

Enzyme Biotechnology and Bioinformatics Unit, Department of Biochemistry, Federal University of Technology, Akure, Nigeria

*Corresponding Author’s Email: moraksanni@yahoo.co.uk

\begin{abstract}
Sorghum (Sorghum bicolor (L) Moench), is used as human food such as bread, malt drinks and beers; as livestock feed, renewable energy source such as bioethanol. The experimental monitoring of enzyme activity during malting permits the detection of germination-specific genes. The products of $\alpha$ - amylase (simple sugars), $\beta$-amylase (maltose), protease (free amino nitrogen) and polyphenol oxidase (quinone), combined during kilning and mashing, with the development of characteristics flavor and coloured malt. In this study, we investigate malting properties of white and yellow varieties of sorghum while the variation in the activity of the three enzymes namely polyphenol oxidases, amylases and proteases, were monitored as the malting progresses. The result obtained were $95 \%$ and $86 \%$ germinative energy, $1.49 \mathrm{~g}$ and $1.09 \mathrm{~g}$ water absorption, $0.751 \mathrm{mg} / \mathrm{ml}$ and $0.639 \mathrm{mg} / \mathrm{ml}$ crude protein for yellow and white sorghum respectively. The activity of the three enzymes was higher in dormant yellow sorghum than dormant white sorghum. For both varieties, polyphenol oxidase activities were lowest during steeping than in dormant grain, while the highest activities were obtained during germination. Amylases activity did not changed significantly from dormant to germination. The proteases activities were highest during steeping than in dormant while gradually decreased to zero level during germination.
\end{abstract}

Keywords: Sorghum, Sorghum bicolor (L) Moench, Malting properties, Polyphenol oxidases, Amylases, Proteases.

\section{INTRODUCTION}

Sorghum (Sorghum bicolor (L) Moench), indigenous to Africa, is a member of the grass family Poaceae. Sorghum is a grain that grows primarily around the equator in semi-arid climates (Owuama 1997). Sorghum is ranked as the fifth most important grain in terms of production, preceded by wheat, rice, maize, and barley (Veith, 2007). The top sorghum producers are Mexico, Nigeria, U.S.A and India. Sorghum, locally called guineacorn, is the most extensively grown cereal grain in the Nigeria (Aba et al., 2004). Two of the best known species are Sorghum vulgare and Sorghum bicolor (L.) Moench. Nigeria is the largest sorghum producer in West Africa, accounting for about $71 \%$ of the total regional sorghum output, and the breweries have continued to use sorghum and corn as the key raw materials despite the barley malt importation in Nigeria (USDA, 2011).

The grain is composed of three main parts: seed coat (pericarp-testa), germ (embryo) and endosperm (storage tissue). The seed coat contains copious amount of polyphenolic compounds which combine with other flavonoids (anthocyanins, anthocyanidins, etc.,) to give it varying colours (Okrah, 2008). The germ fraction of sorghum is rich in minerals (ash), protein and lipids as well as B-group vitamins: thiamine, niacin, and riboflavin which also occur in the aleurone layer (Pomeranz, 1987; Palmer et al., 1989) while the endosperm consists mainly of starch granules, storage proteins and cell-wall materials (Ogbonna, 2011). Sorghum is a source of 
nutrients and bioactive compounds, especially 3deoxyanthocyanidins, tannins, and polycosanols, which beneficially modulate, in vitro and in animals, parameters related to noncommunicable diseases such as obesity, diabetes, dyslipidemia, cardiovascular disease, cancer, and hypertension (Awika, et al., 2009; Farrar, et al., 2008; Kamath, et al., 2007; Kim and Park, 2012; Moraes et al., 2012; Muriu et al., 2002; Shih et al., 2007; Woo, et al., 2012; Yang et al., 2009). It does not contain gluten, which make it suitable for the celiac disease patient.

Sorghum is used as human food such as bread, malt drinks and beer; as livestock feed, renewable energy source such as bioethanol (Dahlberg et al, 2011). Previous studies demonstrated that sorghum plants were able to accumulate large quantities of heavy metal in the shoots, as well as highly tolerant to metal pollution (Roy et al., 2016). The availability of the sorghum full genome sequence (Paterson et al., 2009), makes it a reasonable $\mathrm{C}_{4}$ model plant, which could be combined with the $\mathrm{C}_{3}$ plant models Arabidopsis and rice, to study the gene products involved in adaptation to heavy metal stress. Traditionally, sorghum malting occurs outdoors by placing the steeped sorghum grain in thin layers on covered or uncovered floors. Following a 4-6 day germination period, the green malt is dried in thin layers in the sun (Daiber and Taylor, 1995). The traditional brewing process utilizes malted grain sorghum and two different fermentations. The first fermentation is by lactic acid bacteria to produce lactic acid, which provides the characteristic flavor and lowers the $\mathrm{pH}$, thus reducing microbial growth. The second fermentation is by yeast, Saccharomyces cerevisiae, to produce alcohol (Watson and Novellie 1975).

Malting is the controlled germination of the grain followed by the controlled drying of a seed. The goal of malting is to produce high enzyme activity, endosperm modification, and a characteristic flavor with a minimum loss of dry weight (Hoseney, 1994). Thus, experimental monitoring of enzyme activity during malting will permit the detection of germination-specific genes. Physically sorghum does not contain a husk like barley does, has a higher starch gelatinization temperature, and has less diastatic, $\beta$-amylase, and glucanase activities. Therefore the traditional brewing procedures for barley have to be altered to account for the differences between the grains (Pozo-Insfran et al., 2004). Why malting? Sorghum components, especially its protein is less digestible than other cereals for human and monogastric animals. The removal of these undesirable components during malting improves the nutritional quality of sorghum and effectively utilizes its potential as human food or animal feed. The report of Narsih et al. (2012) showed that, soaking for 24 hours and germination for 36 hours produced sorghum with higher nutritional values.

However, slow digestibility of sorghum starch and protein makes it foods useful in diabetic treatments, in that its polyphenol content mostly tannin, serves as antioxidants.

Alpha-amylase, the liquefying amylase, is an endoenzyme hydrolyzing $\alpha 1 \rightarrow 4$ bonds within amylose and amylopectin that develops during the germination phase of malting (Bamforth 2006; Owuama 1999). Proteases are vital components in the malting process as not only do they provide yeast with a source of free nitrogen, sulphur and amino acids, but they are also important contributors to the clarity, flavour and filterability of both whisky and beer, and are also involved beer foam stability and haze formation (Bamforth, 2006). Enzymatic browning occurs as a result of the oxidation by polyphenol oxidase, of phenolic compounds to quinones and their eventual (non-enzyme-catalyzed) polymerization to melanin pigments (Whitaker, 1996). Polyphenol Oxidase proved to be advantageous in the malting process, involving in the development of flavor and characteristic brown coloration resulted by Strecker degradation, a typical maillard reaction (Yoruk and Marshall, 2003). Thus, the products of amylase (simple sugars), protease (free amino nitrogen) and polyphenol oxidase (quinone) combine during kilning and mashing, leading to the development of characteristics flavor and coloured malt. In this study, we evaluated the malting properties of two variety of sorghum and the behavior of three malting enzymes, namely polyphenol oxidase, amylase and protease.

\section{MATERIALS AND METHODS}

\section{MATERIALS}

\section{Sample collection}

Dried white and yellow Sorghum was purchased from a seller at Oja-oba market in Akure, Nigeria. It was classified as Sorghum bicolor at the Department of Crop and Pest Science of Federal University of Technology Akure, Nigeria.

\section{Apparatus and chemicals}

Top loading balance (OHAUS Inc.), Homogenizer, Measuring cylinder, Micropipette, $\mathrm{pH}$ meter, Beakers, Laboratory oven, Refrigerator, Heating baths, Eppendorf Cold Centrifuge, Spectrophotometer, Catechol , Bovine serum albumin (BSA), Bradford reagent, 3,5dinitrosalisylate reagent (DNS), Potato starch, Casein. All other reagents were all of analytical grade.

\section{METHODS}

\section{Physical analysis}

The weight and volume of 1000 sorghum grain were 
determined in duplicates as described by Makeri et al. (2013). Density was calculated as a ratio of mass of the kernel to its volume in $\mathrm{g} / \mathrm{ml}$.

\section{Determination of the Germinative energy (GE)}

The germinative energy was determined following the method of the Institute of Brewery method (Makeri et al, 2013) and the European Brewery Convention (EBC) method (Frančáková et al, 2012). The 100 grains were germinated in $90 \mathrm{~mm}$ Petri dishes with two layers of filter paper (Whatman No. 1) wetted with $5 \mathrm{ml} \mathrm{H}_{2} \mathrm{O}$. Petri dish was then covered and incubated at an average temperature of $30^{\circ} \mathrm{C}$ for $24-72$ hours. The kernels that shoot (sprouted) at the end of the incubation were counted and expressed as germinative energy.

GE $(\%)=100-\mathrm{N}$; where; GE=Germinative Energy and $\mathrm{N}$ $=$ number of ungerminated grains. OR

GE $(\%)=\left(\mathrm{n}_{24}+\mathrm{n}_{48}+\mathrm{n}_{72}\right)$

where: $n_{24}, n_{48}, n_{72}$ - numbers of germinated kernels at 24,48 , and $72 \mathrm{~h}$

\section{Determination of the germination index (GI)}

The germination index (GI) was calculated from the results of the germination energy determination according to EBC method (Frančáková et al, 2012):

$\mathrm{GI}=10 \times\left(\mathrm{n}_{24}+\mathrm{n}_{48}+\mathrm{n}_{72}\right) /\left(\mathrm{n}_{24}+2 \mathrm{n}_{48}+3 \mathrm{n}_{72}\right)$

where: $n_{24}, n_{48}, n_{72}-$ numbers of germinated kernels at 24,48 , and $72 \mathrm{~h}$

\section{Germinative capacity}

One hundred sorghum grains were placed in a $100 \mathrm{ml}$ glass beaker containing distilled water and steeped at $30^{\circ} \mathrm{C}$ for 48 hours. The steep water was strained off and the sprouted grains separated from the un-sprouted ones and counted. The un-sprouted grains were then transferred onto moist filter papers (Whatman No.1) in petri dishes covered with another moist filter paper and the lid replaced. The dishes were then wrapped in jute bag and allowed to germinate at ambient temperature $\left(32^{\circ} \mathrm{C} \pm 2\right)$ for about 24 hours while water was sprinkled at intervals. Newly germinated grains were counted and the result added to the first (Makeri et al, 2013).

The germinative capacity (GC) was calculated as follows: $\mathrm{GC} \%\left(\mathrm{dH}_{2} \mathrm{O}\right)=(200-\mathrm{N}) / 2$

where; $\mathrm{N}=$ Number of ingeminated grains.

\section{Water sensitivity}

Two lots of 100 grains each were grown on filter papers (Whatman No.1) in petri dishes (9cm diameter); the two

\section{Water absorption}

Hundred (100) sorghum kernels of each cultivar were soaked in a $100 \mathrm{ml}$ beaker containing $50 \mathrm{ml}$ of distilled water at ambient temperature (32oC \pm 2$)$. Steeping was done continuously until constant weights were attained and recorded. Soak waters were drained off the grains by the use of sieves, while soaked grains were weighted at 3hours interval; from $0 \mathrm{hr}$ to $24 \mathrm{~h}$. The water absorbed over the $24 \mathrm{~h}$ soaking period was calculated as the difference between the weights of the original and soaked grains (Makeri et al, 2013).

\section{Malting}

Malting consists of steeping, germination and drying or kilning of sorghum grains (Ogbonna et al, 2012; Makeri et al, 2013).

Steeping: The sorghum grains were steeped at $320 \mathrm{C}$ $( \pm 2)$ for 36 hours as follows: 7 hours steeping: 2 hours air-rest in four cycles. Air-rests were done by draining off the steep water completely.

Germination: After the last 4 hours air-rest, the grains were placed on a rectangular wooden frame that has net, to enable bottom and top air-flow circulation. The grain germinated at room temperature $\left(32^{\circ} \mathrm{C} \pm 2\right)$ with water sprinkled at intervals. The green malts were harvested continuously at 9 hours interval for 72 hours of continuous germination.

\section{Preparation enzyme crude extract}

Twenty-five grams $(25 \mathrm{~g})$ of each sorghum grains were weighed and homogenized with $50 \mathrm{ml}$ of chilled phosphate buffer $(0.1 \mathrm{M}, \mathrm{pH} 6.8)$ for 3 mins and filtered. The filtrate was centrifuged at $10000 \mathrm{rpm}$ at $4^{\circ} \mathrm{C}$ for $15 \mathrm{mins}$. The supernatant was stored and used as crude extract for enzymes assay.

\section{Assay for enzyme activity \\ Determination of $\alpha$-amylase}

Saccharolytic activity of $\alpha$-amylase was measured with the DNSA method (Bernfeld, 1955). The reaction mixture consisted $0.7 \mathrm{ml}$ of $1 \%$ substrate (potato starch) solution dissolved in $0.1 \mathrm{M}$ phosphate buffer ( $\mathrm{pH} \mathrm{6.8)}$, and $0.3 \mathrm{ml}$ of enzyme solution. After incubation at $30^{\circ} \mathrm{C}$ for $5 \mathrm{~min}$ in a thermo stable water bath, the reaction was stopped by the addition of $1 \mathrm{ml}$ of DNSA reagents. Samples were then one moistened with $5 \mathrm{ml}$ and the other with $10 \mathrm{ml}$ water. The difference in the number of grains that germinated in Petri dishes was noted as the water sensitivity value (Makeri et al, 2013). 
Table 1. Malting Properties of Sorghum

\begin{tabular}{lll}
\hline PARAMETERS & \multicolumn{2}{l}{ SORGHUM SAMPLES } \\
\cline { 2 - 3 } & WHITE & YELLOW \\
\cline { 2 - 3 } Weight per 1000 grains & $31.505 \mathrm{~g}$ & $37.645 \mathrm{~g}$ \\
Density & $1.125 \mathrm{~g} / \mathrm{cm}^{3}$ & $1.176 \mathrm{~g} / \mathrm{cm}^{3}$ \\
Germination Energy & $86 \%$ & $95 \%$ \\
Germination Index & 6.98 & 8.12 \\
Germination Capacity & 88.5 & 96.0 \\
Water Sensitivity & 2 & 11 \\
Water Absorption & $1.09 \mathrm{~g}$ & $1.49 \mathrm{~g}$ \\
\hline
\end{tabular}

placed in a boiling water bath for $15 \mathrm{~min}$ and subsequently cooled down to room temperature. Absorbance was measured using a spectrophotometer at $540 \mathrm{~nm}$ against a blank prepared using the identical method, except the enzyme solution was added to the mixture after the addition of the DNSA solution (Dutta et al., 2006).

\section{Determination of Protease Activity}

$0.3 \mathrm{~mL}$ of enzyme extract and $0.3 \mathrm{~mL}$ of $1 \%$ casein prepared in $0.1 \mathrm{M}$ phosphate buffer $\mathrm{pH} 6.8$ were incubated for $1 \mathrm{~h}$ at $37^{\circ} \mathrm{C}$. The reaction was stoppe $\mathrm{d}$ by addition of $2 \mathrm{~mL}$ of $10 \%(\mathrm{v} / \mathrm{v})$ trichloracetic acid (TCA). For the control, the substrate was precipitated with $2 \mathrm{~mL}$ of $10 \%$ TCA before adding the enzyme solution and then treated as described above. After $10 \mathrm{~min}$ on ice, the samples were filtered using Whatman No1 filter paper (Shimogaki et al., 1991). 0.5mL supernatant was then added to $1 \mathrm{~mL}$ of $1 \mathrm{M} \mathrm{NaOH}$, and the absorbance was taken at $440 \mathrm{~nm}$ (Karmous et al., 2012). One unit (U) of protease activity was defined as the amount of the enzyme that increased the absorbance by 0.001 minute $^{-1}$ under the conditions of the assay.

\section{Determination of polyphenol oxidase activities}

The activity of PPO was determined by reaction mixture which contained of $0.1 \mathrm{ml}$ freshly prepared enzyme extract and $0.7 \mathrm{ml}$ of $30 \mathrm{mM}$ catechol in $0.1 \mathrm{M}$ phosphate buffer $\mathrm{pH} 6.8$ incubated for 10 minutes and the absorbance was read at $420 \mathrm{~nm}$. One unit (U) of PPO activity was defined as the amount of the enzyme that increased the absorbance by 0.001 minute $^{-1}$ under the conditions of the assay (Deepaa and Wong, 2012).

\section{Protein determination}

Protein concentration was measured according to the method of Bradford (1976) using bovine serum albumin (BSA).

\section{RESULT AND DISCUSSION}

The white, yellow and cream seed of sorghum have been reported useful for malting and brewing (Abu et al., 2004). Dewar et al. (1997) reported that steeping conditions applied to sorghum brewing indicates malt quality. Measured parameters of diastatic power, FAN content, and extract increased when steeping time was increased from 16 to $40 \mathrm{~h}$ and optimum temperature was between $25^{\circ}$ and $30^{\circ} \mathrm{C}$. The study showed that aeratio $n$ during steeping was necessary to maximize malt quality. Steeping is a very important aspect of sorghum malting, and dilute alkaline steeping improves the overall quality of the malt (Obeta, 1999). A study by Lefydei and Taylor (2006) indicated that steeping in $0.2 \%$ sodium hydroxide solution reduced fungal and bacterial contamination without causing cytotoxicity, along with increasing the diastatic power by increased water absorption in the grains.

The overall performances of white and yellow sorghum follow the same paradigm. The protein concentrations of the crude extract were $0.639 \mathrm{mg} / \mathrm{ml}$ and $0.751 \mathrm{mg} / \mathrm{ml}$ for white and yellow sorghum respectively. This is slightly higher than the amount that was reported by Adefila et al (2012), where $0.59 \mathrm{mg} / \mathrm{ml}$ was obtained for crude enzyme from green malt of Sorghum bicolor. The malting properties obtained in this study (Table 1), showed that white sorghum has lower germinative energy and germinative capacity than the yellow sorghum. Ogbonna (2011) reported a range of $96-97 \%$ and $90.5-$ $96.5 \%$ for germinative energy and germinative capacity respectively for some sorghum varieties. Makeri et al (2013) reported germinative capacities greater than $90 \%$ for some improved Nigeria barley cultivars. Beta et al. (1995) found the germinative energy of 16 sorghum cultivars ranged from 43-99\% while Demuyakor and Ohta (1992) found the germinative energy of sorghum varieties grown in Ghana ranged from $72-90 \%$.

The result of this study showed that polyphenol oxidase activities were lowest during steeping than at dormant seed, while the highest activities were obtained during germination. This indicated the development of brown coloration which is essential for malt production, and this can be optimized and control based on the type 
094 Afr. J. Food Sci. Technol.

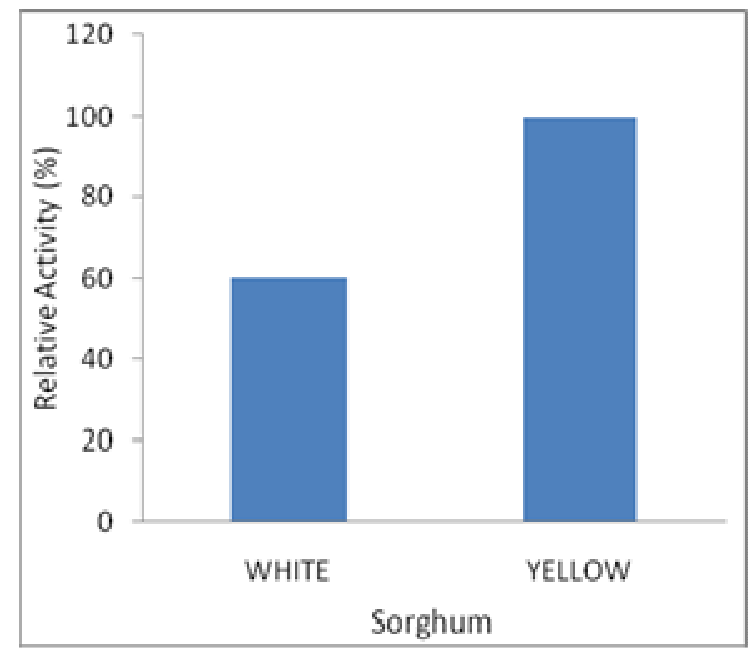

Figure 1. Polyphenol Oxidases Activity in dormant grains $(0$ Hour).

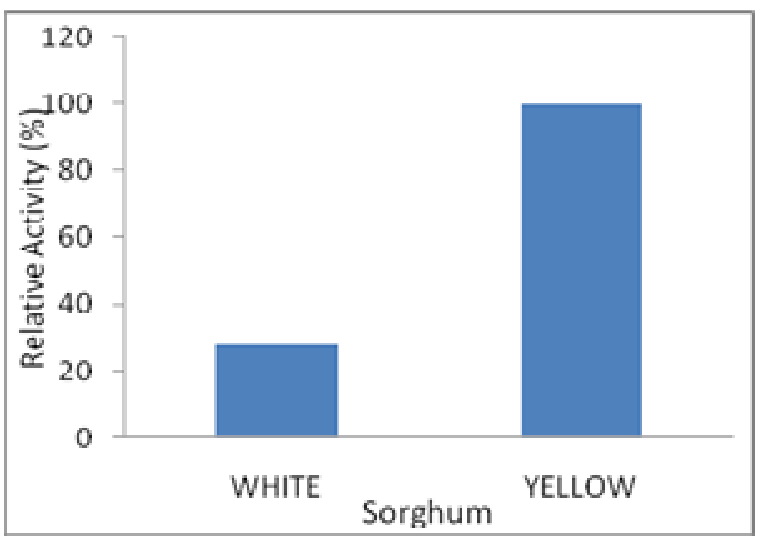

Figure 3. Proteases Activity in dormant grains (0 Hour).

of malt in view. The activities of PPO are possible on the adequate presence of phenolics such as 3deoxyanthocyanidins, tannins, and polycosanols, as in figure 1, 4, 7, and 10. Huynh and Jerumanis (1977) found that polyphenol oxidase activity increased by three fold after steeping.

The result of this study showed that an amylases activity did not change greatly from dormant to germination. This could have negative impact in the malting process in that the amounts of simple sugar or maltose released were unchanged as in figure 2, 5, 8 and 11. Sorghum malting yields high proportions of hydrolytic

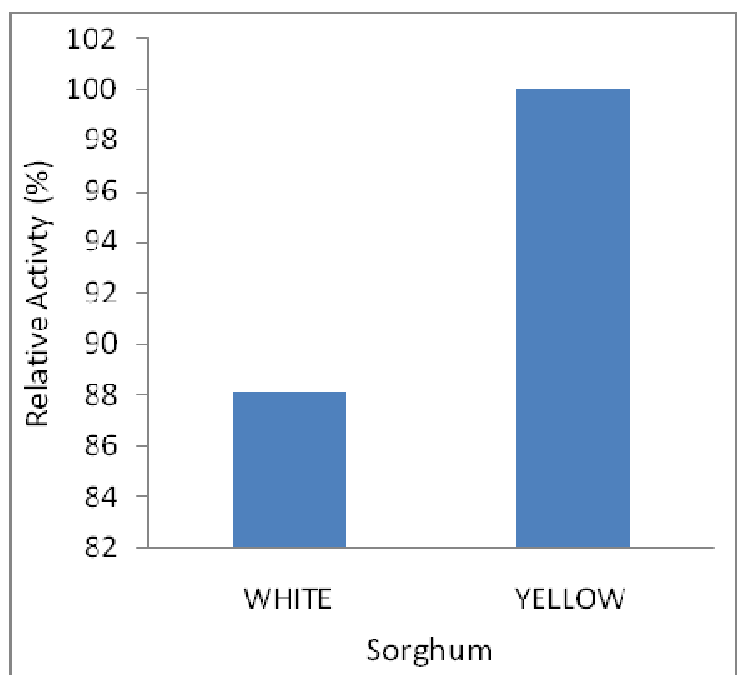

Figure 2. Amylases Activity in dormant grains (0 Hour).

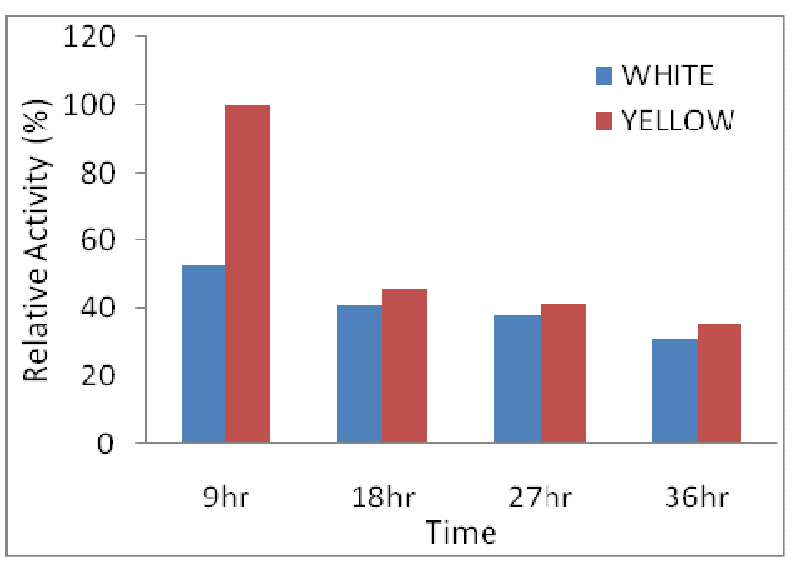

Figure 4. Polyphenol Oxidase Activity at 9 hour intervals during Steeping.

enzymes such as $\alpha$-glucosidase, and $\alpha$ - and $\beta$-amylases (Owuama 1999). Dufour et al. (1992) evaluated 49 different sorghum cultivars grown in 10 different Asian and Africa nations and found that eighty percent of the sorghum malts exhibited $\alpha$-amylase activities similar to or higher than industrial lager barley malts, and that the white sorghums in the study performed better in malting and brewing than red sorghum. Taylor (1994) found that sorghum has a lower ratio of $\beta$ - to $\alpha$ - amylase (0.2), which limits the conversion of starch to simple sugars. Aisien and Ghosh (1978) report that $\alpha$-amylase rather than $\beta$ amylase is the primary amylase that degrades 

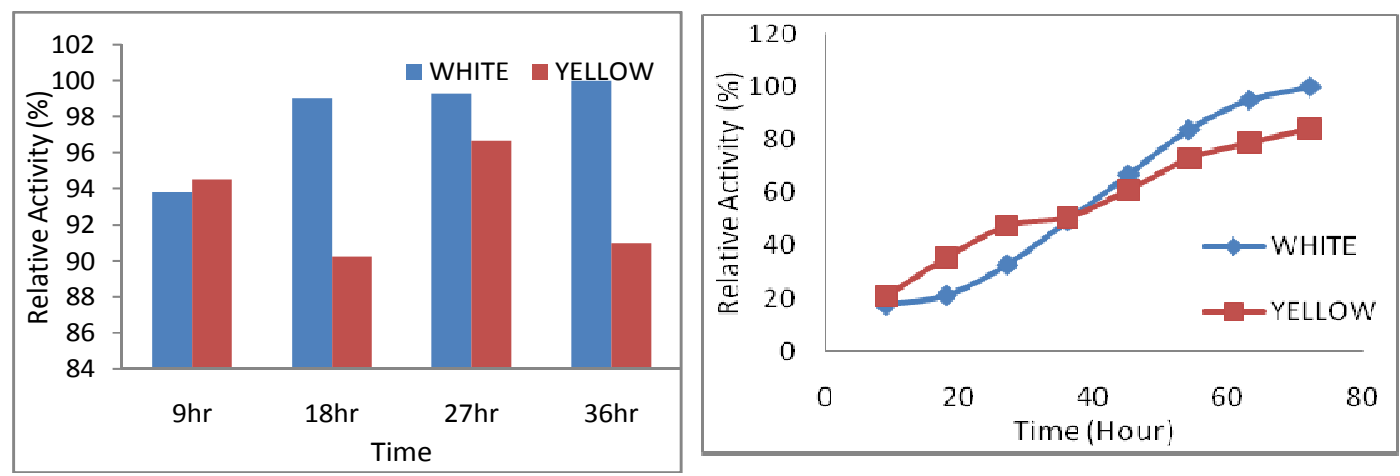

Figure 5. Amylases Activity at 9 hour intervals during

Figure 7. Polyphenol Oxidase Activity at 9 hour intervals Steeping. during Germination.
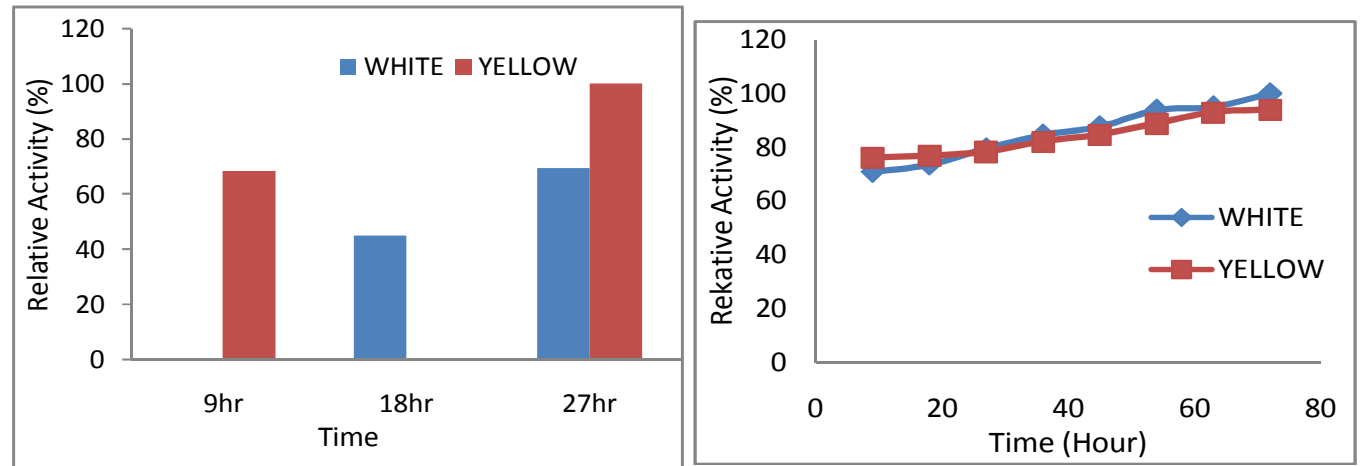

Figure 6. Proteases Activity at 9 hour intervals during Steeping.

Figure 8. Amylases Activity at 9 hour intervals during Germination.

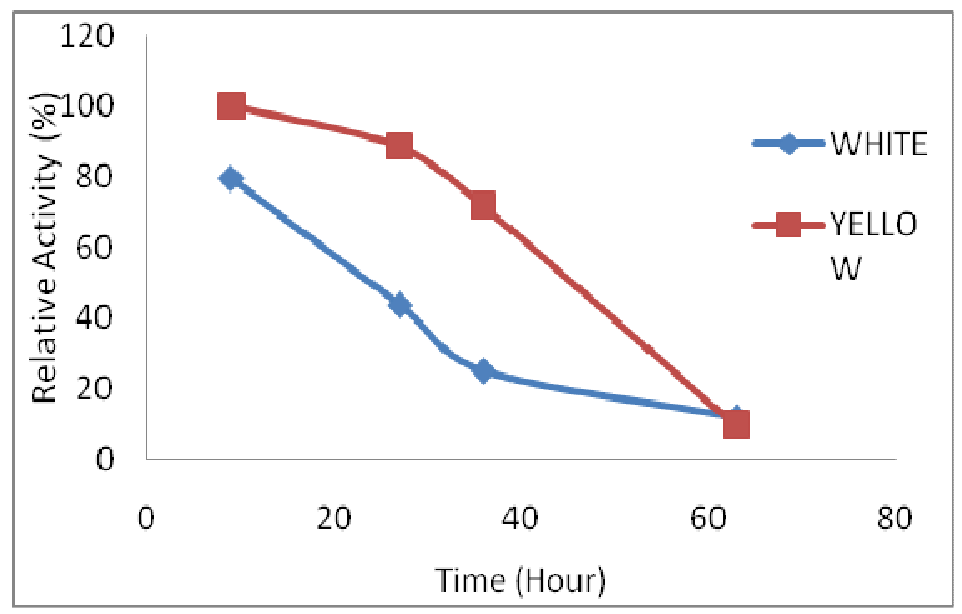

Figure 9. Proteases Activity at 9 hour intervals during Germination.

starch during malting. $\beta$-amylase, the saccharifying amylase, catalyzes the hydrolysis of $\alpha(1 \rightarrow 4)$ glucosidic bond at a non-reducing end of polysaccharides, causing the release of maltose. It has been reported that ungerminated sorghum grain exhibits virtually no $\beta$-amylase activity (Owuama 1999).

The result of this study showed that the proteases activities were highest during steeping than in dormant while gradually decreased to zero level during germination. This indicated the production of free $\alpha-$ 
096 Afr. J. Food Sci. Technol.

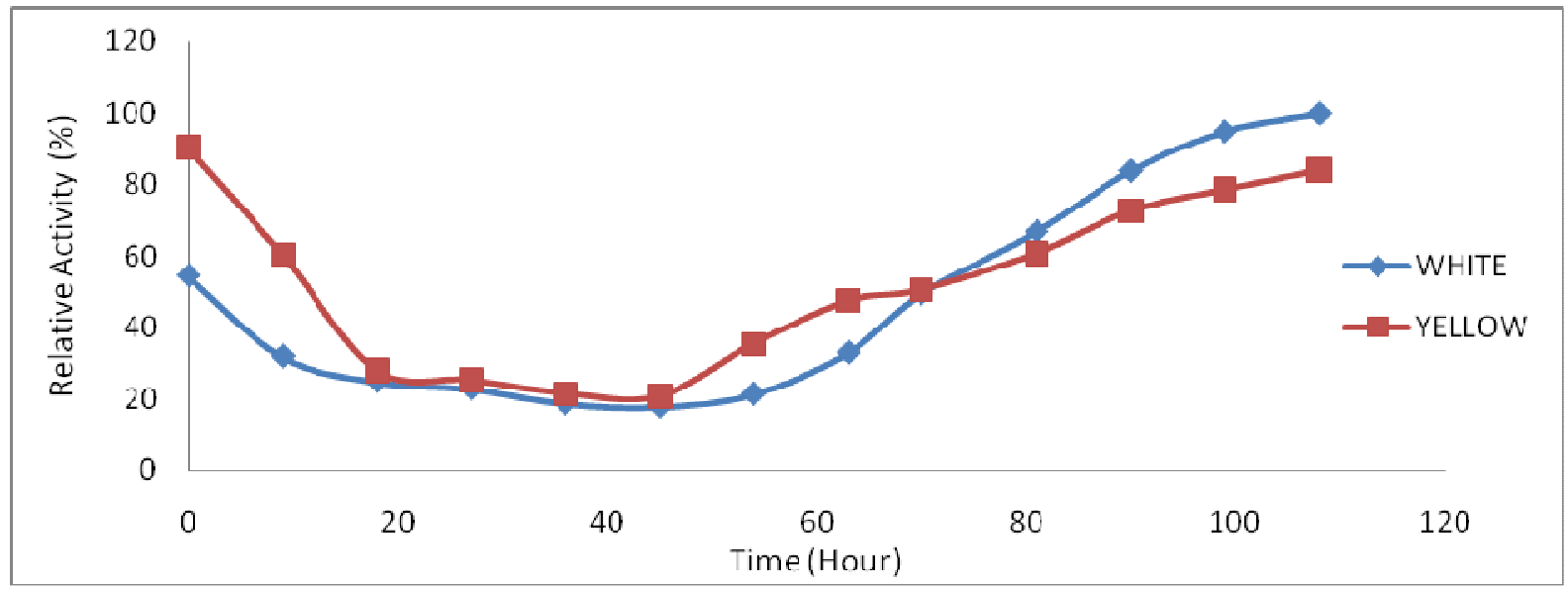

Figure 10. Polyphenol Oxidase Activities during Sorghum Malting. Dormant $=0$ hour. Steeping $=0-36$ hours. Germination $=36-108$ hours.

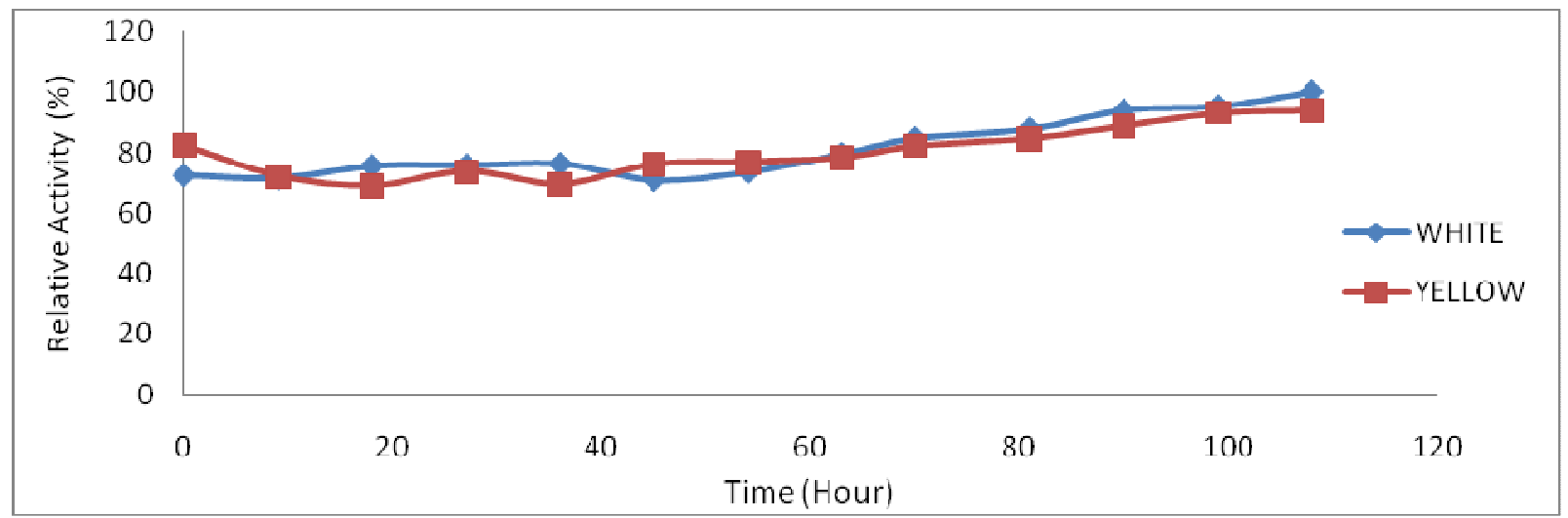

Figure 11. Alpha-amylase Activities during Sorghum Malting. Dormant $=0$ hour. Steeping $=0-36$ hours. Germination $=36-108$ hours.

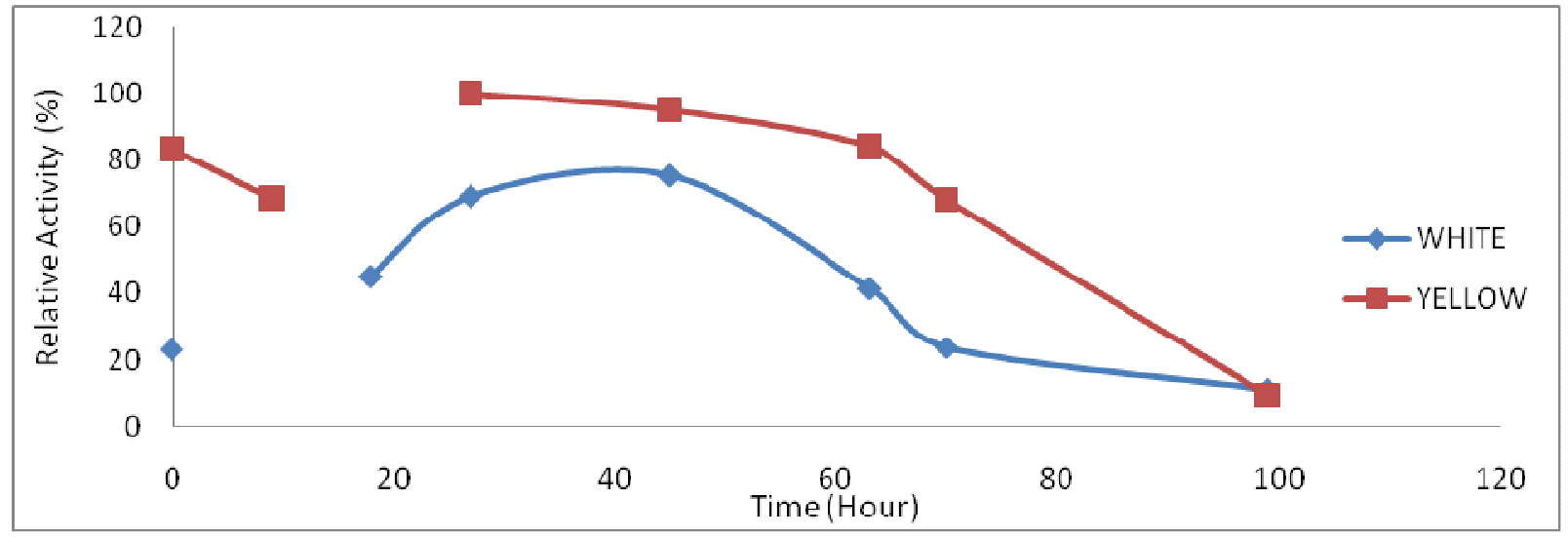

Figure 12. Protease Activities during Sorghum Malting. Dormant $=0$ hour. Steeping $=0-36$ hours. Germination $=36-108$ hours.

amino nitrogen (FAN), as in figure 3, 6, 9 and 12. The carboxypeptidase and proteinase enzyme activities in three sorghum malts has been reported (Ogbonna et al.,
2003). Endopeptidases including carboxypeptidases and proteinases are important in grain germination to hydrolyze proteins into FAN, which is necessary for yeast 
metabolism (Owuama 1999). Afify et al., (2012), observed that after germination, crude protein was decreased and free amino acids were increased.

\section{CONCLUSION}

We have been able to provide data for industrial production of sorghum malt. Based on the result of this study, polyphenol oxidase like the other well known malting enzymes such as amylases and proteases, proved to be greatly expressed during germination stage of malting, and it is important in the colour development of malt before kilning. Thus, to obtain the highest levels of sugars, free amino nitrogen, and quinone, the amylases, proteases and polyphenol oxidases activities and other malting conditions need to be controlled and optimized.

\section{REFERENCES}

Aba DA, Idem NUA, Marley PS, Maigida DN (2004). Sorghum. Idem, N.U.A \& Showemimo F.A (eds.) Cereal crops of Nigeria: principles of production and utilization. Zaria: Ade Commercial Press. 38-78.

Adefila OA, Bakare MK, Adewale $\mathrm{IO}(2012)$. Characterization of an aamylase from sorghum (Sorghum bicolor) obtained under optimized conditions. J. Inst. Brew.; 118: 63-69.

Afify AE-MMR, El-Beltagi HS, Abd El-Salam SM, Omran AA (2012). Protein Solubility, Digestibility and Fractionation after Germination of Sorghum Varieties. PLoS ONE 7(2): e31154. doi:10.1371/journal.pone.0031154.

Agu RC(2005). Some relationships between enzyme development extract recovery, and sugar profile in malted sorghum. Technical Quarterly of the Master Brewers Association of the Americas. 42(2):120-124

Aisen AO, Ghosh BP(1978). Preliminary studies of the germination behavior of guinea corn (Sorghum vulgare). J. Food Sci. and Agric. 29(10):850-852.

Awika JM, Yang L, Browning JD, Faraj A(2009). Comparative antioxidant, antiproliferative and phase II enzyme inducing potential of sorghum (Sorghum bicolor) varieties. LWT - Food Science and Technology 42:1041-1046.

Bamforth CW(2006). Scientific principles of malting and brewing American Society of Brewing Chemists. St. Paul, MN.

Bernfeld $\mathrm{P}(1955)$. Amylase a and b. Methods in Enzymology. 1, 149151

Beta T, Rooney LW, Waniska RD(1995). Malting characteristics of sorghum cultivars. Cereal Chemistry. 72(6):533-538.

Bradford MM(1976). A rapid and sensitive method for the quantitation of microgram quantities of protein utilizing the principle of protein dye binding. Analyt. Biochem. 72: 248-254.

Dahlberg Jeff, Janoš Berenji, Vladimir Sikora, Dragana Latković, (2011): Assessing sorghum [Sorghum bicolor(L) Moench] germplasm for new traits: food, fuels \& unique uses. Advance Access Publication, Maydica 56-1750.

Daiber KH, Taylor JRN(1995). Opaque beer. As found in Dendy, D.A.V. 1995. Sorghum and millets: chemistry and technology. American Association of Cereal Chemists, Inc. St. Paul, MNVol. 3, No. 1.

Deepaa Manohan, Wong Chen Wai(2012). Characterization of Polyphenol Oxidase in Sweet Potato (Ipomoea Batatas (L.)). Journal for the Advancement of Science \& Arts,

Demuyakor B, Ohta Y(1992). Malt characteristics of Sorghum vulgare varieties from Ghana. J. Food Sci. and Agric. 59:457-492.

Dewar J, Taylor JRN, Berjak P(1997). Determination of improved steeping conditions for sorghum malting. J. Cereal Sci. 26:129-136.
Dufour JP, Mélotte L, Srebrink S(1992). Sorghum malts for the production of lager beer. J. the American Society of Brewing Chemists. 50(3):110-119.

Dutta Tapan Kr, Malabendu Jana, Priti R. Pahari, Tanmay Bhattacharya (2006). The Effect of Temperature, $\mathrm{pH}$, and Salt on Amylase in Heliodiaptomus viduus(Gurney) (Crustacea: Copepoda: Calanoida). Turk J. Zool, 30, 187-195.

Farrar JL, Hartle DK, Hargrove JL, Greenspan P(2008). A novel nutraceutical property of select sorghum (Sorghum bicolor) brans: inhibition of protein glycation. Phytotherapy Research 22:1052-1056.

Frančáková H, Líšková M, Bojňanská T, Mareček J(2012): Germination index as an indicator of malting potential. Czech J. Food Sci., 30: 377-384.

Hoseney RC(1994). Principles of cereal science and technology. 2nd ed. American Association of Cereal Chemists. St. Paul, MN.

Huynh NV, Jerumanis J(1977) Study on Barley and Malt Polyphenol oxidase.I. Chromatography of Barley, Steeped Barley, and Malt Polyphenol oxidase ASBC Journal, 35(4): 153-159.

Kamath, V, Niketh S, Chandrashekar A, Rajini PS(2007). Chymotryptic hydrolysates of $\alpha$-kafirin, the storage protein of sorghum (Sorghum bicolor) exhibited angiotensin converting enzyme inhibitory activity. Food Chemistry 100:306-311.

Karmous Inès, Jaouani Khadija, Abdelilah Chaoui, Ezzedine El Ferjani, (2012). Proteolytic activities in Phaseolus vulgaris cotyledons under copper stress. Physiol Mol Biol Plants, 18(4):337-343. DOI 10.1007/s12298-012-0128-4

Kim J, Park Y(2012). Anti-diabetic effect of sorghumextract on hepatic gluconeogenesis of streptozotocin-induced diabetic rats. Nutrition \& metabolism 9:1-7.

Lefydei ML, Taylor JRN(2006). Effect of dilute alkaline steeping on the microbial contamination, toxicity, and diastatic power of sorghum malt. Journal of the Institute of Brewing. 112(2):108-116.

Makeri MU, Nkama I, Badau MH (2013). Physico-chemical, malting and biochemical properties of some improved Nigerian barley cultivars and their malts. Intl. Food Res. J. 20(4): 1563-1568.

Moraes ÉA, Natal DIG, Queiroz VAV, Schaffert RE, Cecon PR, de Paula SO, Benjamim Ld A, Ribeiro SMR, Martino HSD(2012). Sorghum genotype may reduce low-grade inflammatory response and oxidative stress and maintains jejunum morphology of rats fed a hyperlipidic diet. Food Res. Intl. 49:553559.

Muriu JI, Njoka-Njiru EN, Tuitoek JK, Nanua JN (2002). Evaluation of sorghum (Sorghum bicolor) as replacement for maize in the diet of growing rabbits (Oryctolagus cuniculus). Asian-Australasian $\mathrm{J}$. Animal Sci., 15:565-569

Narsih, Yunianta and Harijono (2012). The study of germination and soaking time to improve nutritional quality of sorghum seed. International Food Research Journal, 19(4): 1429-1432.

Ogbonna $\mathrm{AC}(2011)$. Current developments in malting and brewing trials with sorghum in Nigeria: A Review. Journal of Institute of Brewing, 117, 394-400.

Ogbonna AC, Christian IA, Ekaette OI, Ukpong SU. (2012). Effect of Malting Conditions on The Nutritional And Anti-Nutritional Factors of Sorghum Grist. AUDJG - Food Technology 36(2) 64-72.

Ogbonna AC, Obi SKC, Okolo BN, Odibo FJC(2003). Purification and some properties of a protease from sorghum malt variety KSV8-11. J. Inst. Brew. 109:51-56.

Okrah SG(2008). Screening of six local sorghum varieties for their malting and brewing qualities. M.Sc thesis, Kwame Nkrumah Uni Sci Tech., Ghana.

Owuama Cl (1999). Brewing beer with sorghum. Journal of the Institute of Brewing. 105(1):23-34.

Owuama $\mathrm{Cl}(1997)$. Review sorghum: a cereal with lager beer brewing potential. World Journal of Microbiology and Biotechnology. 13:253260.

Palmer GH, Etokakpan OU, Igyor MA(1989). Review: sorghum as brewing raw material. MIRCEN Journal, 5, 265-275.

Paterson AH, Bowers JE, Bruggmann R, Dubchak I, Grimwood J, Gundlach $\mathrm{H}$, et al., (2009). The Sorghum bicolorgenome and the diversification of grasses. Nature.; 457(7229):551-6. doi:10.1038/nature07723PMID:19189423 
098 Afr. J. Food Sci. Technol.

Pomeranz Y(1987). Modern Cereal Science and Technology. VCH, New York.

Pozo-Insfran DD, Urias-Lugo D, Hernandez-Brenes C, Saldivar SOS(2004). Effect of amyglucosidase on wort composition and fermentable carbohydrate depletion in sorghum lager beer. Journal of the Institute of Brewing. 110(2):124-132.

Roy SK, Cho S-W, Kwon SJ, Kamal AHM, Kim SW, Oh MW, et al. (2016) Morpho-Physiological and Proteome Level Responses to Cadmium Stress in Sorghum. PLoS ONE 11(2): e0150431. doi:10.1371/journal.pone. 0150431

Shih CH, Siu Ng, R Wong, E. Chiu, LC M, Chu IK, Lo C(2007). Quantitative analysis of anticancer 3-deoxyanthocyanidins in infected sorghum seedlings. J. agric. and food chem., 55:254-259.

Shimogaki H, Takeuchi K, Nishino T, Ohdera M, Kudo T, Ohba K, Iwama M, Irie M(1991). Purification and Properties of a Novel Surface-active Agent- and Alkaline-resistant Protease from Bacillus sp. Y. Agric. Biol. Chem., 55 (9), 2251-2258.

Taylor JRN, Dewar J(1994). Role of alpha-glucosidase in the fermentable sugar composition of sorghum malt mashes. Journal of the Institute of Brewing. 100:417-419.

Veith N. Kirstin (2007). Evaluation Of Four Sorghum Hybrids Through The Development Of Gluten-Free Beer. MSc Thesis, Food Science Department, Kansas State University, Manhattan, Kansas, USA.

Watson TG, Novellie L(1976). The development of amylase and maltase during the malting of Sorghum vulgare. Agrochemophysica. $7(4): 61-74$

Whitaker JR,(1996). Polyphenol oxidase. In Food chemistry (O.R. Fennema, ed.)pp. 492-494, Marcel Dekker New York
Woo HJ, Oh IT, Lee JY, Jun DY, Seu MC, Woo KS, Nam MH, Kim $\mathrm{YH}(2012)$. Apigeninidin induces apoptosis through activation of Bak and Bax and subsequent mediation of mitochondrial damage in human promyelocytic leukemia $\mathrm{HL}-60$ cells. Process Biochemistry 47:1861-1871.

Yang L, Browning JD, Awika JM (2009). Sorghum 3deoxyanthocyanins possess strong phase II enzyme inducer activity and cancer cell growth inhibition properties. Journal of agricultural and food chemistry 57:1797-1804.

Yoruk R, Marshall MR (2003). Physicochemical properties and function of plant polyphenol oxidase: a review. J. Food Biochem., 27, 361422. 